
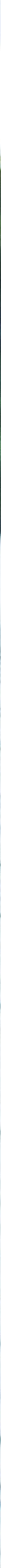



\section{Stimulating Textile-to-Textile Recycling}

David Watson, Maria Elander, Anja Gylling, Tova Andersson and Pirjo Heikkilä

TemaNord 2017:569 


\section{Stimulating Textile-to-Textile Recycling}

David Watson, Maria Elander, Anja Gylling, Tova Andersson and Pirjo Heikkilä

ISBN 978-92-893-5274-1 (PRINT)

ISBN 978-92-893-5275-8 (PDF)

ISBN 978-92-893-5276-5 (EPUB)

http://dx.doi.org/10.6027/TN2017-569

TemaNord 2017:569

ISSN 0908-6692

Standard: PDF/UA-1

ISO 14289-1

(c) Nordic Council of Ministers 2017

Cover photo: unsplash.com

Print: Rosendahls

Printed in Denmark

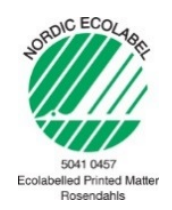

\section{Disclaimer}

This publication was funded by the Nordic Council of Ministers. However, the content does not necessarily reflect the Nordic Council of Ministers' views, opinions, attitudes or recommendations.

Rights and permissions

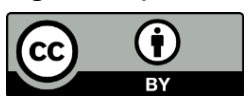

This work is made available under the Creative Commons Attribution 4.0 International license (CC BY 4.0) https://creativecommons.org/licenses/by/4.0.

Translations: If you translate this work, please include the following disclaimer: This translation was not produced by the Nordic Council of Ministers and should not be construed as official. The Nordic Council of Ministers cannot be held responsible for the translation or any errors in it.

Adaptations: If you adapt this work, please include the following disclaimer along with the attribution: This is an adaptation of an original work by the Nordic Council of Ministers. Responsibility for the views and opinions expressed in the adaptation rests solely with its author(s). The views and opinions in this adaptation have not been approved by the Nordic Council of Ministers. 
Third-party content: The Nordic Council of Ministers does not necessarily own every single part of this work. The Nordic Council of Ministers cannot, therefore, guarantee that the reuse of third-party content does not infringe the copyright of the third party. If you wish to reuse any third-party content, you bear the risks associated with any such rights violations. You are responsible for determining whether there is a need to obtain permission for the use of third-party content, and if so, for obtaining the relevant permission from the copyright holder. Examples of third-party content may include, but are not limited to, tables, figures or images.

Photo rights (further permission required for reuse)

Any queries regarding rights and licences should be addressed to:

Nordic Council of Ministers/Publication Unit

Ved Stranden 18

DK-1061 Copenhagen K

Denmark

Phone +4533960200

pub@norden.org

\section{Nordic co-operation}

Nordic co-operation is one of the world's most extensive forms of regional collaboration, involving Denmark, Finland, Iceland, Norway, Sweden, and the Faroe Islands, Greenland and Åland.

Nordic co-operation has firm traditions in politics, economics and culture and plays an important role in European and international forums. The Nordic community strives for a strong Nordic Region in a strong Europe.

Nordic co-operation promotes regional interests and values in a global world. The values shared by the Nordic countries help make the region one of the most innovative and competitive in the world.

The Nordic Council of Ministers

Nordens Hus

Ved Stranden 18

DK-1061 Copenhagen K, Denmark

Tel.: +4533960200 www.norden.org

Download Nordic publications at www.norden.org/nordpub 



\section{Contents}

Summary. .7

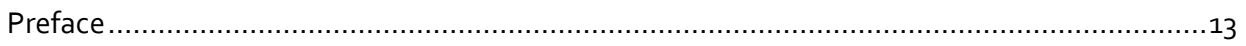

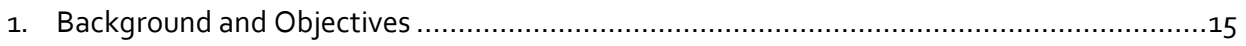

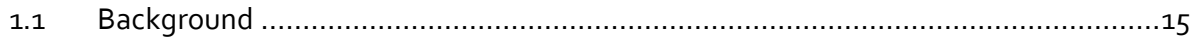

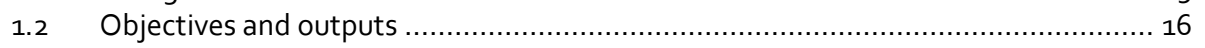

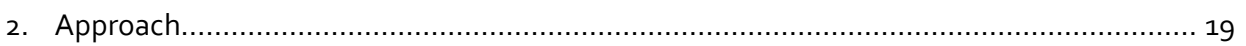

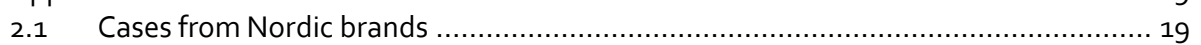

2.2 The three pillars of engagement ................................................................ 19

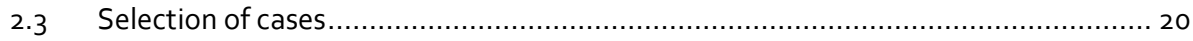

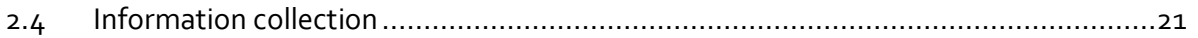

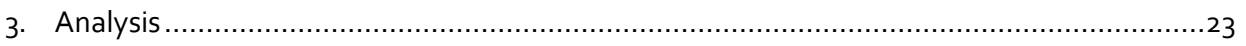

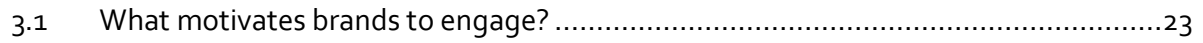

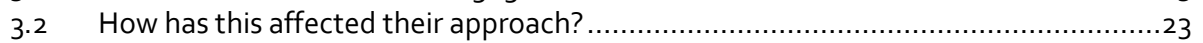

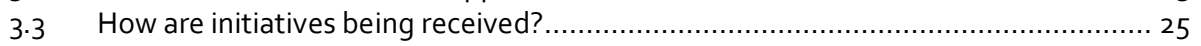

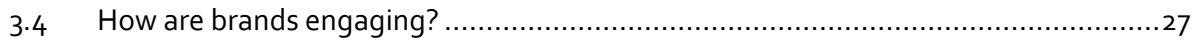

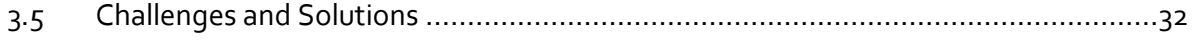

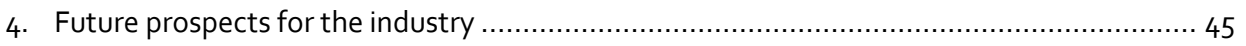

4.1 Shifting the use of recycled fibres from niche to mainstream .............................. 45

4.2 Value chain dialogue for increased use of recycled fibres and design for recycling ... 46

4.3 Common quality requirements on recycled textile fibres ......................................47

4.4 Strategic coalition for increased marked demand for recycled fibres......................47

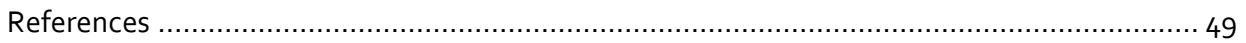

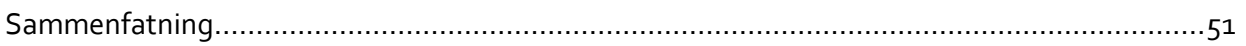





\section{Summary}

\section{Background}

Extending the active lifetimes of textile products via reuse and other means is a key way to reduce the environmental impacts of textile products and should be prioritised. However, all textiles eventually become worn out and must be handled as waste. Material recycling of textile waste back into new textile products, is environmentally advantageous compared to incineration or landfill, but is currently limited in extent.

In 2015, the Nordic Council of Ministers launched an action plan for sustainable fashion and textiles; Well Dressed in a Clean Environment. One of its objectives is to "promote business models that stimulate recycling of fibres into new textile products".

This current project achieves that objective through three key outputs:

- A case wallet ${ }^{1}$ presenting 10 cases of brands that are engaging in circular thinking. The case wallet is intended to inspire other brands both in the Nordic countries and elsewhere.

- This report that includes a cross-case analysis of challenges that brands have experienced and strategies they have selected to overcome these.

- A workshop held in Stockholm on 27 September 2017, that brought together brands, suppliers of recycled yarns, used textile collection organisations and researchers, with the aim of increasing cooperation and cementing partnerships.

\section{Nordic brands on the pathway to recycling}

Stimulating textile-to-textile recycling of textiles requires effort at both ends of the value chain. A reliable supply of recyclable used textiles needs to be secured, and the demand for recycled-content fibres and yarns needs to be increased.

A number of Nordic brands have been venturing out on pathways towards textileto-textile recycling both through designing for ease of recycling and thus increase potential supply, and through using recycled materials in new products. Eleven such brands and some of their key partners were interviewed to identify their motivation, challenges they've experienced, how they overcame these and perspectives for the industry as a whole.

${ }^{1}$ Published simultaneously by Nordic Council of Ministers: Textile-To-Textile Recycling: Ten Nordic brands that are leading the way. 


\section{Responding to pressure on resources}

Brands are responding to a growing recognition that the industry should take responsibility to reduce its pressure on raw resources in the face of growing global demand. Switching to a circular economy also has long-term strategic importance for the industry itself in order to secure supplies of materials.

\section{Most focus on recycled content}

All interviewed brands are making use of yarns/fabrics with recycled content in selected new products. They are using a range of recovered materials: polyester recycled from PET bottles, nylon from fishing nets and mechanically recycled cotton and wool. Two of the brands are "re-making" new products from recovered post-consumer fabrics. Some of the brands are also designing products for ease of recycling, through avoiding fibre and material blends or design for ease of separation of different materials.

Fewer are developing or are part of closed-loop systems. These require not only designing of products from which materials can be recovered for the next generation, but also systems to collect post-consumer products.

\section{A constantly changing picture}

Our picture is a snapshot of a moving scene. All the brands we spoke to have committed to moving more deeply into circular thinking in the future. For many the starting point has been to use readily accessible and consistent quality recycled fibres such as recycled PET or pre-consumer cotton waste from factories.

Design for ease of recycling lies further along the process, in part because its usefulness is dependent on effective systems for collection and processing of postconsumer waste. Design for recycling may eventually lead to take-back systems, which once in place, can act as a catalyst for spreading closed-loop thinking to other products.

All the brands are engaging in recycling as part of a wider sustainability or circular economy agenda. In this context, several brands stressed that using recycled fibres and fabrics must not compromise durability or quality. Partly because this would compromise their brand, but also because a longer lifetime gives higher environmental savings. Not all brands are so aware of this priority.

All brands have experienced challenges when implementing circular thinking, but they have also developed strategies to overcome these. These strategies can potentially be implemented by other brands wishing to engage. 


\section{Commitment at leadership level}

Engaging in the use of recycled-content may affect margins during the first phases. Recycled-content yarns are often more expensive than virgin, and venturing outside the regular supply chain requires new routines in the company. Therefore, it is key that there is a drive for engagement at leadership level.

\section{Working closely with suppliers}

Using recycled fibres in new clothing, and designing for ease of recycling through, for example, using fabrics made from a single fibre type, can impact on other wished for product qualities like durability, comfort, low-weight and stretch. Brands have tackled this through close cooperation with their suppliers in an iterative development of fabrics that both meet functional needs while including recycled content or being readily recyclable. One brand took this a stage further by taking over the production of recycled-content yarns.

Once recycled or recyclable fabrics/yarns have been developed, these can be made readily available to a brand's designers for use in future products. One brand developed a material library with sustainable choices for each set of characteristics a designer is looking for.

\section{Communicating with consumers}

By strongly communicating to customers on why a brand is engaging in the use of recycled materials and designing for circularity, it may be possible to increase prices to cover additional costs. It may also be possible to change what customers expect in terms of the quality and feel of a product during early piloting of recycled content. Sustainability can be communicated as another form of quality.

\section{Using transparency and traceability standards}

It is important for brands to gain assurance that what they are purchasing as recycled content, really does contain recycled materials, and that the recycled content does not contain harmful chemicals. Some brands make use of standards such as the Global Recycle Standard and Bluesign to provide such assurance. 


\section{From niche to mainstream}

Although circular thinking has arrived on the agenda for many brands, its application remains relatively niche. A general recognition among brands is that the industry needs be proactive and not wait for consumer demand for circular products. The industry should be actively developing and offering such products and exploring new options.

Government and the media have a role to play: government by creating incentives for the industry to engage, and the media by increasing consumer awareness of the circular economy.

Meanwhile, demonstration by frontrunners that circular approaches can be profitable can be a significant factor in encouraging more brands to follow suit. There is also a need for better knowledge, standards and education for designers on how to design circular garments.

\section{The importance of networks and partnerships}

The circular economy is likely to require closer partnerships in the future. Taking part in networks such as Mistra Future Fashion, Ellen MacArthur Foundation and others have provided brands with knowledge of the current status of recycling innovation and technology. Closing material loops will also require greater cooperation. Material exchange partnerships such as ECO CIRCLE and material exchange platform Re.Verso have demonstrated the potential of increasing cooperation between brands and suppliers via material exchange hubs and recycling companies. If the industry is to become circular on a broad scale this type of cooperation will need to become more widespread. Some brands also see a potential for small brands to collaborate when approaching suppliers. This would give suppliers greater confidence in developing new products.

\section{Coordinated research and development}

Many of the interviewed brands see developments in the future that will overcome many of today's challenges. This includes breakthroughs in chemical recycling techniques that will allow recycling of mixed fibre products and allow the materials in clothing to be re-circulated over many product generations. Such processes would need a consistent and large supply of waste textiles. In this context, there is a need for automated sorting machines that can rapidly and cost-effectively sort non-reusable textiles by colour and fibre type. Both types of technology are under development in various pilots and research programmes but brands recognise a need for greater coordination of these efforts. 


\section{Don't wait to engage}

Although, the development of these technologies will change the map, the interviewed brands were in agreement that the industry should not wait for these technologies to arrive. "Work with what you have" was a common mantra. By engaging now in developing and marketing recycled-content garments, by setting up collection systems for post-consumer products and by designing for recycling, brands are paving the way for more rapid adoption of new technologies as they arise. 



\section{Preface}

The project was carried out in the period from November 2016 to October 2017 by experts from organisations in three Nordic countries:

- David Watson and Anja Charlotte Gylling, PlanMiljø, Denmark

- Maria Elander and Tova Andersson, IVL, Sweden

- Pirjo Heikkilä, VTT, Finland

The project was led by David Watson (PlanMiljø). It was funded by the Nordic Working Group for Waste (NAG) and coordinated by Emilie Mille Müller and Anne-Mette Lysemose Bendsen from the Danish EPA.

The project group wishes to thank representatives from the 11 Nordic textile brands and some of their key partners who were interviewed, for their time and input without which this project would have been impossible. 



\section{Background and Objectives}

\subsection{Background}

The Nordic Environmental Action Programme 2013-18 includes an aim that the Nordic region's global footprint should be reduced. The consumption of textiles has been shown by various studies to be one of the most impacting European consumption areas after mobility, food and housing (EEA, 2013; JRC, 2014; Tukker et al. 2006 etc.). Nordic consumption of textiles is relatively high by European standards: Danish, Swedish, Norwegian and Finnish and Icelandic citizens consume between $13 \mathrm{~kg}$ and $16 \mathrm{~kg}$ of new textiles each year (Tojo et al., 2012; Palm et al., 2014).

Over the last few years, reducing the environmental impacts of textiles has been a key issue for the Nordic Council of Ministers (NCM). The Prime Minister's Green Growth Initiative and the Nordic action plan for sustainable fashion and textiles Well Dressed in a Clean Environment include objectives to increase the collection, reuse and recycling of used textiles in the Nordic countries. The action plan also includes a goal to promote business models that stimulate recycling of fibres into new textile products.

An LCA-based report for the Nordic Council of Ministers shows that reuse gives far greater environmental benefits than recycling, which itself is environmentally advantageous compared to incineration with energy recovery, though the advantages are small compared to those of reuse (Schmidt et al., 2016). The report also found that benefits of recycling tend to be higher for recycling options where recycled fibres are used in new textile products.

Care should be taken not to prioritise recycling over reuse as is also stressed by the EU waste hierarchy. This is currently ensured via strong economic signals (Watson et al., 2016). Moreover, while reuse is thriving under charity-based collection and export systems, recycling options for the non-reusable share, and especially textile to textile recycling are more restricted (Palm et al., 2014).

That said, there are a number European companies engaged in mechanical textile recycling (i.e. SOEX and I:Collect) and some pilot/demonstration projects for higher quality recycling underway. These include pilot projects developing various methods for (chemical) recycling of fibres - e.g. Relooping Fashion in Finland and Re:newcell in Sweden - and R\&D projects on automated sorting of fibres as feed-in to recycling processes - e.g. SIPTex ${ }^{2}$ and Textile back to Textiles $^{3}$ (Sweden), Textiles4Textiles (Netherlands) and FIBRESORT (Belgium).

\footnotetext{
${ }^{2}$ http://www2.vinnova.se/sv/Resultat/Projekt/Effekta/2011-01544/SIPTex--Svensk-Innovationsplattform-forTextilsortering/

3 https://wargoninnovation.se/projekt/textiles-back-to-textile/
} 
A range of stakeholders, including fashion companies and other textile companies, collectors and recyclers have an interest in increasing the fibre-to-fibre recycling of textiles but face challenges in doing so (Elander \& Ljungkvist, 2016).

Some of these challenges are technical including shortening fibre lengths, separation of fibre types in products with fibre mixes and the presence of persistent chemicals in some specialised products. Others are system problems related to gathering and sorting sufficient quantities of recyclable used textiles and at the same time not offsetting environmental preferable reuse pathways (Elander \& Ljungkvist, 2016).

Moreover, the economics of fibre-to-fibre recycling remain marginal with current technologies and in currently available volumes (Thompson et al., 2012).

These challenges cannot be met by a single group or in a single place in the value chain. There is a clear need for increased coordination and exchange of information between actors; in particular between designers/brands/producers and sorters/ recycling companies and technicians developing new recycling technologies (Elander \& Ljungkvist, 2016).

An increase in textile to textile recycling of textiles requires effort at both ends of the value chain. A reliable supply of recyclable used textiles needs to be secured and the demand for fibres, yarns and fabrics with recycled-content needs to be increased.

\subsection{Objectives and outputs}

The overall objective of the project is to contribute to an increased demand for, and supply of recycled textile materials as inputs into new (textile) products to ensure a more sustainable development of the fashion and textile industry. The specific project objectives are

- to increase knowledge amongst key stakeholders of the opportunities and obstacles to recycling of textiles and how these can be implemented and overcome

- to bring stakeholders across the value chain together to work on these issues.

The project has a double focus: analysing examples of textile products designed to be recycled post-consumption ("push"); and on developing products using recycled materials ("pull") and disseminating these to relevant actors. Of special interest are examples of full closed loops. This is explained in more detail in the next chapter. 
The project has three key outputs that in combination aim to achieve the project objectives:

- A Case Wallet ${ }^{4}$ of 10 cases of Nordic brands that are already engaging in one or more of these areas. The case wallet is intended to inspire other brands both in the Nordic countries and elsewhere.

- This Report that pulls out common themes and messages from the cases, including challenges and ways in which these have been overcome. The report is aimed at industry stakeholders and policymakers.

- A Workshop bringing together brands, suppliers, recyclers and other important stakeholders with the aim of increasing cooperation and cementing partnerships.

The workshop was held in Stockholm on 27 September 2017 back-to-back with Mistra Future Fashion's annual meeting. This project has no official connection to the Swedish MFF research programme 5 but there are a number of good synergies between the work.

Cases were presented by some of the brands included in the case wallet and then discussions took place via organised sessions. Arranging the workshop in connection with the MFF meeting ensured a high participation rate by relevant stakeholders. More than 50 representatives from brands, suppliers of recycled yarns, recyclers, take-back organisations, researchers and policymakers contributed to a lively exchange of experiences, ideas and solutions.

\footnotetext{
4 Published simultaneously by Nordic Council of Ministers: Textile-To-Textile Recycling: Ten Nordic brands that are leading the way.

5 http://mistrafuturefashion.com/
} 



\section{Approach}

\subsection{Cases from Nordic brands}

This project centres on experiences of Nordic brands that are engaging in textile recycling in one way or another, and on their downstream and upstream partners.

An overview of the experiences and activities of ten brands is presented in a case wallet ${ }^{6}$ aimed specifically at inspiring other brands. The cases also form the core of the research material that is presented in this report.

By digging deeply into the brands' experiences we can find out why they are engaging, where they have encountered challenges and how they have overcome these. We can also learn something of where they are heading, and what their longterm goals are.

Finally, they have given us their opinions concerning challenges facing the industry as a whole with respect to recycling, and how these need to be tackled through cooperation and development of initiatives along and across the value chain.

\subsection{The three pillars of engagement}

In this project we focus on textile-to-textile recycling. We are also focussed on handson initiatives; examples of brands that are engaging in practical initiatives within textile-to-textile recycling. These fall into the following broad areas:

- Use of recycled-content fibres/fabrics in new textile products

- Design of products to enable textile-to-textile recycling using existing processes

- Engagement in closed loop systems

The final area is a holistic approach that combines the first two. Under a fully closed loop system a brand can take back their own used products, and recover materials as input to a new generation of the same product. Here the loop may include other actors such as take-back agents, recyclers, spinners, etc. but the material eventually ends back with the same company.

However, there are other examples that we can loosely call collective closed loops. These typically have a hub or recycling organisation at the centre. This organisation takes used textiles from a number of brands for recycling and then redistributes the

${ }^{6}$ Published simultaneously by Nordic Council of Ministers: Textile-To-Textile Recycling: Ten Nordic brands that are leading the way. 
recovered/fibres, or yarns and fabrics that have been produced from these fibres back to the brands. The hub may also have connections with recyclers and yarn/fabric producers that carry out the processing. EcoCircle and Re.Verso are two examples of collective closed loop platforms (see Box 1).

Box 1: Collective close loop initiatives

ECO CIRCLE is a global collective closed loop system for $100 \%$ polyester products. The ECO CIRCLE iniiative is led by Japanese chemical company, Teijin. ECO CIRCLE's over 130 global members take back their own post-consumer $100 \%$ polyester products and send them to Teijin for chemical recycling. The members may also buy recycled polyester pellets or yarns back from Teijin for use in new products.

The Milan-based company C.L.A.S.S (Creativity Lifestyle and Sustainable Synergy) and Gucci have established an exchange platform, Re.Verso, for recycled materials with partners across the textile value chain. Via the hub, producers of textile products provide mills with pre-consumer, or in some cases post-consumer, textile waste (mostly wool but also other fibre types) which they process into new yarns. In turn, participating partners can purchase yarns with recycled content back via the Re.Verso platform. All recycled content exchanged via Re.Verso can be traced back to its original source.

There are many different types of companies and organisations that are involved in initiatives within these three themes: brands, recyclers, hubs, yarn and fabric producers, technical universities etc. For this project we have chosen to have a brand as the central actor in each case but also describe other actors involved in the particular initiative.

\subsection{Selection of cases}

Our selection criteria for our ten cases were as follows:

- The collected cases should cover all three broad types of initiatives as far as possible.

- The collected cases should cover a range of fibre types - not limited to cases on polyester for example.

- The collected cases should come from across the Nordic region as far as possible.

- The initiative should be reasonably well advanced - at least one product mobilising the initiative should be on the market.

- Brands should be willing to work with us and to share their experiences with others. 
We found over 20 Nordic brands engaging in one or more of the three theme areas. These were identified through the consultants' own knowledge of the theme, via contacts with branch organisations and via Internet search. First contact was taken with the more interesting cases to check how far advanced the initiatives were and to find out whether the brands at the centre were willing to share with us and with others in the industry.

A final selection of 10 brands was made. The selection was carried out in dialogue with the project owners. The brands are as follows.

Table 1: overview of brands included in the case wallet and cross-cutting study

$\begin{array}{llll}\text { Brand } & \text { Head office } & \text { Brand type } & \begin{array}{l}\text { Company size } \\ \text { (employees) }\end{array} \\ & \text { SE } & \text { Men's, women's, children's wear } & \text { Very large }(>10,000) \\ \text { H\&M } & \text { SE } & \text { Outdoor and urban } & \text { Medium }(51-250) \\ \text { Peak Performance } & \text { SE } & \text { Women's and children's wear } & \text { Large }(250-10,000) \\ \text { Lindex } & \text { SE } & \text { Women's and men's high end } & \text { Large (approx. 350) } \\ \text { Filippa K } & \text { SE } & \text { Outdoor } & \text { Small (10-49) } \\ \text { Houdini Sportswear } & \text { FI } & \text { T-shirts, hoodie, sweatshirts } & \text { Small (10-49 } \\ \text { Pure Waste } & \text { FI } & \text { Uniforms, workwear } & \text { Medium (51-250) } \\ \text { Touchpoint } & \text { DK } & \text { Carpets } & \text { Medium (51-250) } \\ \text { Egetæpper } & \text { DK } & \text { Duvets and pillows } & \text { Small (10-49) } \\ \text { Nortex } & \text { DK } & \text { Urban wear } & \text { Micro (less than 10) } \\ \text { Elsk } & & & \end{array}$

The brands cover a good range of different textile types, cover all three themes that we are interested in (see later) and have a reasonably good coverage of the large Nordic countries. The exception is Norway. Approaches were made to several Norwegian brands but it was not possible to agree a close cooperation due either to a lack of willingness to share information or lack of time to engage.

It was only after the deadline for finalising cases had passed, that successful contact was made with Norwegian clothing brand Dressmann. Although Dressmann does not have a case in the accompanying case wallet, the brand has given us information that is included in the cross-cutting analysis.

\subsection{Information collection}

We gathered information from brands and suppliers via semi-structured interviews with company representatives. The representatives' roles in the company differed depending on the size of the company. For large and some medium-sized companies it was typically the sustainability manager, for smaller companies it was designers or material managers and for micro-start-ups it was the one of the founders.

Interviews were guided by questions that had been sent out to the representative beforehand. For brands, these included questions on all three theme areas. Under each theme we asked about the companies' own activities, experiences and motivations but

7 http://ec.europa.eu/growth/smes/business-friendly-environment/sme-definition_en 
also their opinions on what it would take for the wider industry to engage in use of recycled fibres and fabrics and in design for recycling.

The brands were also asked about partnerships that had assisted them in overcoming challenges; upstream suppliers of recycled materials or yarns/fabrics with recycled content, downstream receivers of brands own used clothing, take-back partners and research institutions or networks.

We followed these pathways and carried out interviews with a number of the partners to gain their perspectives that could differ somewhat in character from the brands.

We asked them about their motivation, how had they engaged, and whether they only answered a demand or had themselves been proactive in pushing forward on recycled content etc. 


\section{Analysis}

\subsection{What motivates brands to engage?}

The stated motivation of brands to engage in use of recycled materials and in designing for recycling was surprisingly consistent. It was an understanding that pressure on material resources will increase in the future as the global population grows, and that alternative sources of materials are needed to take pressure off scarce resources.

This stated motivation was of a CSR nature, anchored in an awareness of the large environmental impacts of the textile industry, and the need for the brand to take a greater responsibility for these impacts.

"Economists say that a company functions just to make money, but we think differently. Companies also have to take responsibility for their use of natural resources and move towards recycled materials."

Only a single brand mentioned direct economic incentives in using recycled material, at least in the short term. Recycled materials remain, for the time being, more expensive than virgin resources. Two further brands do, however, expect use of recycled materials to bring economic benefits in the future as the market matures.

Two brands also named basic survival considerations for the industry; namely securing access to resource supplies in the future as virgin supplies dwindle. One of them questioned whether it would have any long-term future if it did not begin the transition to circularity now.

"We need to make the change to circular models if we want to be successful in 2030. We are using a step by step method to achieve this."

\subsection{How has this affected their approach?}

The broad CSR-nature of the majority of the brands' motivation has strongly influenced their approaches to circular thinking.

Firstly, thinking circularly is typically only one dimension in a set of wider sustainability goals and activities. These wider goals often concern the use of "sustainable" materials, minimising resource use or reducing the environmental impacts of the brands' products. 
How "sustainable materials" is interpreted varies but typically includes organically grown fibres, fibres extracted from other waste products and/or fibre types with lower environmental pressures than the mainstream cotton and polyester.

"Adoption of goals at leadership level is key since using these materials will impact margins during the transition period."

For the larger established brands, the wider sustainability goals are part of a transition from the way they have been doing business and they have adopted concrete goals for the transitions (see Box 2).

Box 2: Examples of brands' concrete goals

- Filippa K - By 2030 Filippa K's entire collection will be designed and produced following the principles of circular economy - reduce, repair, reuse and recycle.

- $\quad \mathrm{H} \& \mathrm{M}-\mathrm{By} 2030$ the company will only use recycled or other sustainably-sourced materials in production.

- Lindex - by 2020 at least $80 \%$ of the brand's garments will be designed and produced with sustainability in mind.

- Peak Performance - by $2020,50 \%$ of the polyester and nylon in their collections will be from recycled sources. The company is currently developing broader sustainability goals for all its products.

Some of the smaller brands, on the other hand, report having had sustainability at the core of their business models from the outset or relatively soon after the outset. This is true for Pure Waste, Touchpoint, Elsk and Houdini. Many of these brands, don't have sustainability managers. Rather sustainability issues play a central role in product design and in other company activities. They are not viewed as an add-on.

A second result of the broader CSR-based motivation for engaging in circular thinking is that many of the brands reported that circular initiatives have buy-in at leadership level. This is important since, at least during the first stages of development, use of recycled fibres and design for easier recycling comes at a cost to the brand.

While all the brands are engaging in recycling as part of a wider sustainability or circular economy agenda, it is not clear whether all brands have deeply considered the extent to which use of recycled fibres and design for recycling is compatible with or in conflict with other, more important principles of the circular economy.

"We choose the most appropriate environmental strategy for a given product. In most cases this means designing for durability. Where recycled content or designing for recyclability conflicts with durability, we avoid this." 
Filippa K, Houdini Sportswear, Touchpoint and Nortex are examples of brands that prioritise durability and a long life over and above recycling as the better means for reducing environmental impacts. This fits with the latest research in the area (see e.g. Schmidt et al., 2016). For these companies, using recycled fibres/fabrics or design for recycling must not compromise durability.

Some other brands seem less aware of the waste hierarchy, which is also encapsulated in the technical butterfly wing of the circular economy (see Ellen MacArthur Foundation, 2012). Alternatively, recycling may simply fit better with their business models than initiatives aimed at prolonging product lifetimes.

\subsection{How are initiatives being received?}

The approaches and experiences of brands differ with respect to customer response. Nortex, Touchpoint and to a large extent, Egetæpper, have organisations as their main customers, while the other brands sell exclusively to private individuals.

\subsubsection{By organisations}

Egetæpper finds that use of recycled fibres is positively received when selling to organisations, particularly if the building where they are installing carpets is expected to live up to green building certification standards.

"Using recycled materials in our products is a positive story we can tell our clients, and has been good for our profile. It helps us differentiate ourselves from our competitors."

Nortex Care, a department selling Nortex duvets and pillows to the healthcare sector reports interest from hospital procurers in products with recycled content. However, procurers are often hindered in purchasing these via direction from the leadership in hospitals who demand that procurers focus on purchase price. This may change in the future as political pressure increases in Nordic countries on green public procurement (see, for example, Watson \& Fischer-Bogason, 2017) and the public sector may become an important driver of fibre recycling (Rijkswaterstaat, 2017).

"Our customers are positively surprised when they find that our work clothes look and feel as good as if they were made from virgin materials. Style and visual appeal are key to our collections."

Touchpoint, meanwhile, reports meeting initial scepticism from clients when proposing the use of recycled fibres and fabrics in new uniforms and work wear. Clients are concerned that the recycled content will compromise quality, strength and comfort. The company has found that the best means for tackling this is via user 
testing. This invariably convinces clients who then become positive advocates for Touchpoint's approach.

\subsubsection{By private individuals}

Brands selling to private consumers report that products with recycled content are wellreceived, particularly as consumer awareness of environmental impacts of textiles has increased. Some brands noted, however, that strong communication is needed to inform consumers of why the brand is engaging in products with recycled content. Storytelling is important.

"We communicate to our consumers that recycled content is a quality characteristic that is just as valuable as the feel of material and style of garment. Sustainability is a story that needs to be told."

Several brands noted that it is important that products with recycled content are just as stylish and good looking and of equal high quality as products from virgin fibres/materials to overcome a perception among consumers that recycled material is grey and rough.

The same is true where fibre type is exchanged with a type for which using recycled content has less effect on strength. For example, Filippa $\mathrm{K}$ found some scepticism concerning their recycled polyester products due to public perception that polyester is a less comfortable and lower quality material than cotton. This scepticism disappeared following use and experience of the products.

Interestingly, Lindex experiences far higher media and consumer interest for its upcycled/remake ${ }^{8}$ products than it does for its products that include recycled fibres. This may be due to the novelty value of these items, and the fact that the re-maker needs to be creative in its use of used fabrics.

"The interest in our upcycled denim sneaker and the Redesign collection was huge. I think the media and customers really liked the story behind and the fact that these products are unique, limited items. Products from industrial recycled material don't gain that kind of interest."

Where brands are engaging in design for ease of recycling they have so far been less proactive in communicating these initiatives to consumers. However, where brands such as Houdini have established take-back systems to regain ownership of their products for recirculation and eventual recycling, consumer engagement and communication in this initiative is essential.

${ }^{8}$ Products sewn from used fabrics. 


\subsection{How are brands engaging?}

As described in Section 2.2, this project focuses on three principle areas of engagement in the stimulation of recycling in the industry:

- Use of fibres, yarns and fabrics with recycled content in new textile products

- Design of products to enable textile-to-textile recycling using existing processes

- Engagement in closed loop systems

Figure 1 gives an overview of how the 11 brands we interviewed are engaging within these three areas. The full picture is somewhat more complex and nuanced than Figure 1 suggests. The picture is also under constant development as brands progress through various stages.

\subsubsection{Use of recycled materials}

All 11 brands are using recycled materials in some products. Pure Waste is the only brand that is using recycled material in all its products. For most of the other brands, recycled content products make up a relatively small proportion of the product range; some have so far only a single product line.

However, and importantly, all the brands we interviewed have plans to expand recycled content to more of their collections and products.

The recycled content they currently use comes from a range of sources. Many (e.g. Houdini, H\&M, Nortex, Filippa K, Lindex, Peak Performance, Egetæpper, Pure Waste, Touchpoint) are using recycled polyester from used PET bottles. This is the most readily available source of recycled fibres for use in yarns and has reliable consistency in quality. It is often the first stepping-stone for brands in their pathway towards greener materials (see Figure 3 later).

However, the supply of used PET bottles cannot supply all future demand for recycled fibres especially when competing with other industries for this material, and brands are also using and investigating other recycled materials.

Egetæpper, for example, is using recycled PET bottles for the underside of its carpets and recycled nylon for the upper layer. The nylon has been recycled from used fishing nets by partner company, Econyl. This is a more technically challenging process since used fishing nets contain fine silt that needs to be removed during the recycling process. However, by expanding into new sources of recycled fibres the company is increasing the potential for a more circular economy. H\&M is also making use of polyamide from recycled fishing nets. 
Figure 1: Engagement of interviewed brands in the three themes

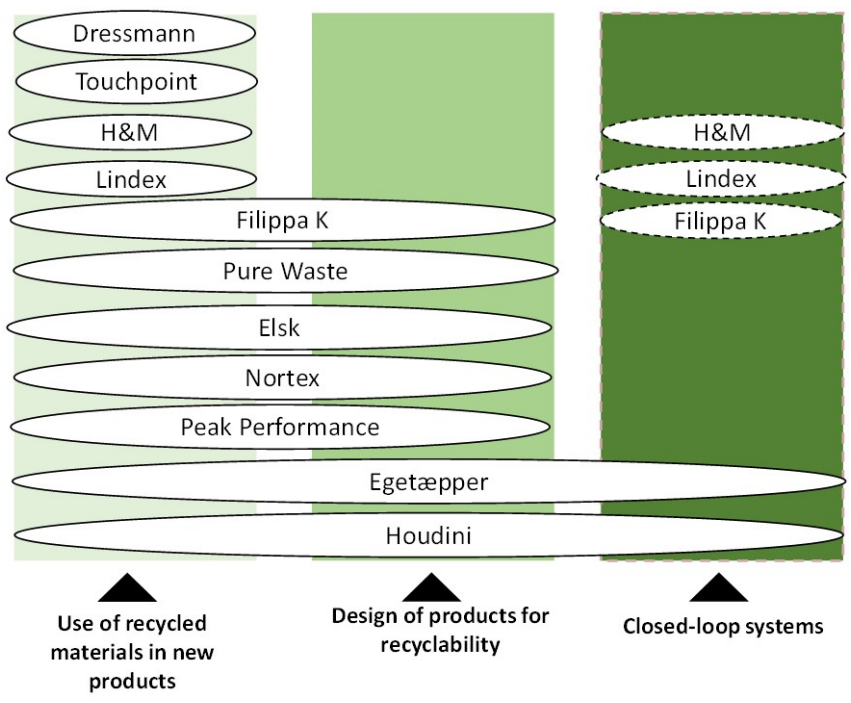

Note: The brands with dashed borders in the right hand column are partially but not wholly engaging in closed loops e.g. they may have set up a take-back system but not with a feed-back loop to their new products, or are using materials from others take-back systems.

The longer-term aim for many brands is to use material recycled from textile waste.

Houdini already uses polyester recycled from used textile products. This is sourced from recycling company Teijin who are at the centre of closed loop system ECO CIRCLE (see Box 1 earlier).

Other brands are using mechanically recycled cotton - in each case mechanically recycled. Pure Waste uses pre-consumer factory waste. Pre-consumer cotton waste has fibre length similar to virgin cotton and Pure Waste has developed technology and processes that allow products to be produced from $100 \%$ recycled cotton.

"Mechanical recycling can only be done so many times. The fibres get shorter and therefore weaker each time; and we have to blend them with virgin fibres. We are eagerly awaiting breakthroughs in chemical recycling that will open the door to endless generations of recycled yarns."

For brands such as Lindex and H\&M that use mechanically recycled post-consumer cotton, technical ceilings for recycled content is far lower; typically $20-30 \%$. Higher shares than this compromise fabric quality and strength too much.

Filippa K, Dressmann and Houdini, meanwhile, are using recycled wool in some products. For Filippa $\mathrm{K}$ this is pre-consumer wool waste that it receives via material platform Re.Verso (see Box 1). Houdini is using post-consumer wool on a small scale but aims to expand use of this in the future. Post-consumer wool waste can be used in higher shares in new products than cotton because the unravelling process is less hard on the fibres. 
Filippa K sources pre-consumer wool waste that has been sorted by colour to avoid the need for re-dyeing. This gives additional environmental benefits of recycling.

\subsubsection{Design for recyclability}

Fewer of the interviewed brands are engaging in design for recycling. This also reflects what we found when searching for potential cases among Nordic brands. However, more plan to in the future (see Figure 2).

Figure 2: Engagement of interviewed brands in design for recyclability

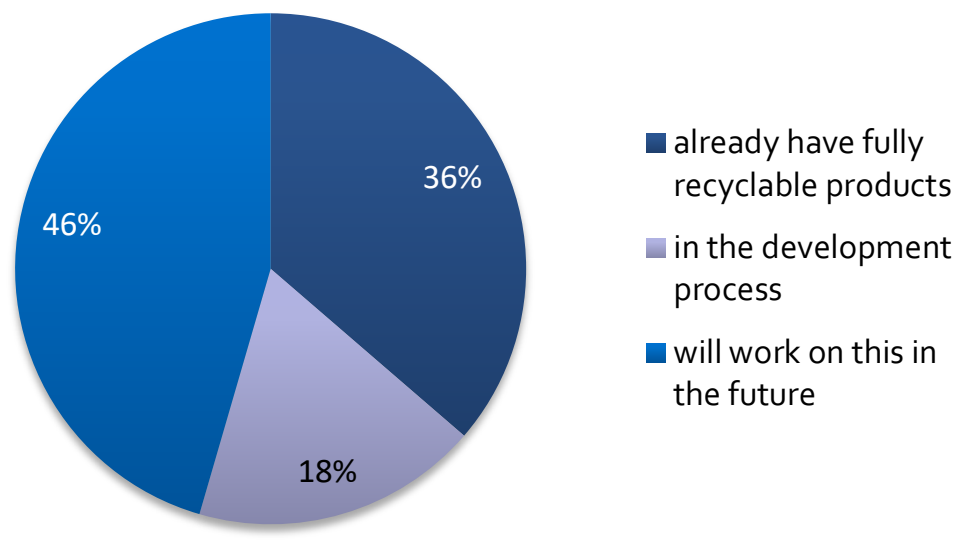

Elsk, Houdini, Pure Waste and Peak Performance's approach to design for recycling is to avoid, where possible, mixing different materials in a single product. For example, avoiding fibre mixes such as polyester/cotton since these can't currently be separated in recycling processes. The exception for Elsk is thread used for sewing garments. Here a cotton/polyester mix is used to provide necessary strength.

The mono-material policy also extends to fasteners and other accessories. Brands like Pure Waste and Elsk avoid inclusion of these where possible. Where Houdini does use fasteners on a polyester shell, these are also produced from 100\% polyester. Pure Waste avoids using hang labels to avoid mixing textile fibre types. Instead the brand uses information labels printed directly on the product using dissolvable water-based dyes. Water-based dyes are also used, where possible, for other prints, though this is difficult when printing on dark clothing.

Where mono-materials are not technically feasible due to different functional needs of various components of the product, ease of disassembly is an option. This is being pursued by Egetæpper, which is designing its carpets to allow easy separation of the heavy underside material from the upper textile layer. Pure Waste also designs zips to be easily removable.

Nortex is aiming for full recyclability in the future but beginning with the relatively simple outer envelope of its duvets and pillows. These were already polyester, with no zips and therefore $100 \%$ recyclable. Nortex recyclability design efforts have focussed 
on choosing dyes that give reasonable colours in second-generation, recycled content duvet covers.

\subsubsection{Closed-loop thinking}

Five of the 11 brands are involved in closed loop thinking. Two of these - Houdini and Egetæpper - can be said to be working within full closed loops. The other three have initiatives that have relevance to closed loops.

"Closed loop systems are not only about designing for ease of recycling, but also about establishing systems for getting products back end-of-life. This is far from easy."

As mentioned before Houdini is part of the global collective closed loop system ECO CIRCLE. ECO CIRCLE's over 130 global members take-back their used $100 \%$ polyester products and send them to Japanese-based Teijin for recycling (see Box 1 earlier). The members may also buy recycled polyester back from Teijin for use in new products.

To be a part of this closed-loop system Houdini has set up a take-back system for Houdini brand clothing in its Swedish stores. This is not only to provide stock for the ECO CIRCLE closed loop system. Reusable used products that are delivered are resold to new users. Once a take-back system is in place this gives impetus to closed-loop thinking for other products and materials. Houdini has yet to find a recycling solution for returned used nylon products, but is storing these until a solution has been found.

"We've established take-back systems in Scandinavian and now want to expand this. But for each new country you have to deal with different infrastructure and a different legal framework concerning ownership."

Egetæpper is in a similar situation. It has also established a take-back system for its carpets in Denmark and elsewhere in the Nordic region as a first stage in closed loop concept. The company is busy developing recycling solutions for the various components of the take-back carpets.

While take-back systems open the door to full closed loops, some companies don't believe that it makes sense for all brands to collect their own products. Small fashion brand Elsk for example believes that for a small brand like itself, a dedicated take-back system, would lead to ineffective and wasteful logistics. As described earlier they are designing for ease of recycling but as part of a much wider collective system.

Despite it's much larger size, H\&M also sees the future in collective systems. The brand has established a global collection system in partnership with used textile logistics company I:Collect, but it accepts all brands, not just it's own. H\&M is not yet implementing design for recycling in its products, but is waiting for development of technology that can separate fibres of different material types from one another. The 
company has partnered with UK-based chemical recycling innovation developer Worn Again.

Lindex is also yet to engage in design for recycling but is nevertheless engaging in one closed loop initiative. In partnership with charity Myrorna which collects used clothing, it is up-cycling used jeans into new products such as denim sneakers. Upcycling is one means for developing 2nd generation garments without the need to make drastic design changes to the first generation.

Finally, Fillipa $\mathrm{K}$ is engaged with sustainable material matchmaking hub C.L.A.S.S and is a partner in the Re.Verso exchange platform for recycled wool and other fibres (see Box 1 earlier). Re.Verso has potential to act as a collective closed loop platform but currently mostly trades in pre-consumer rather than post-consumer textile waste.

\subsubsection{A journey from use of recycled materials towards closed loops}

Figure 1 shows that while all the brands we interviewed make use of recycled materials in new products, fewer are designing for recycling and fewer still are involved in closed loop models.

"We are constantly looking into new options and opportunities in our search for more sustainable fibres and ways to produce our products. These need to be upscalable so we can fulfil our ambitious goals."

It is important to reflect that our picture is a snapshot of a moving scene. All the brands we have spoken to are in a development process (loosely illustrated in Figure 3) and what we are seeing now is in many cases only the first stages. For many, the more obvious starting point in the journey is to use recycled fibres and materials in new products. Moreover, the availability and purity of used PET bottles have meant that recycled $\mathrm{PET}$ is the easiest material to use in the first phase. 
Figure 3: Typical transition pathways towards textile-to-textile recycling

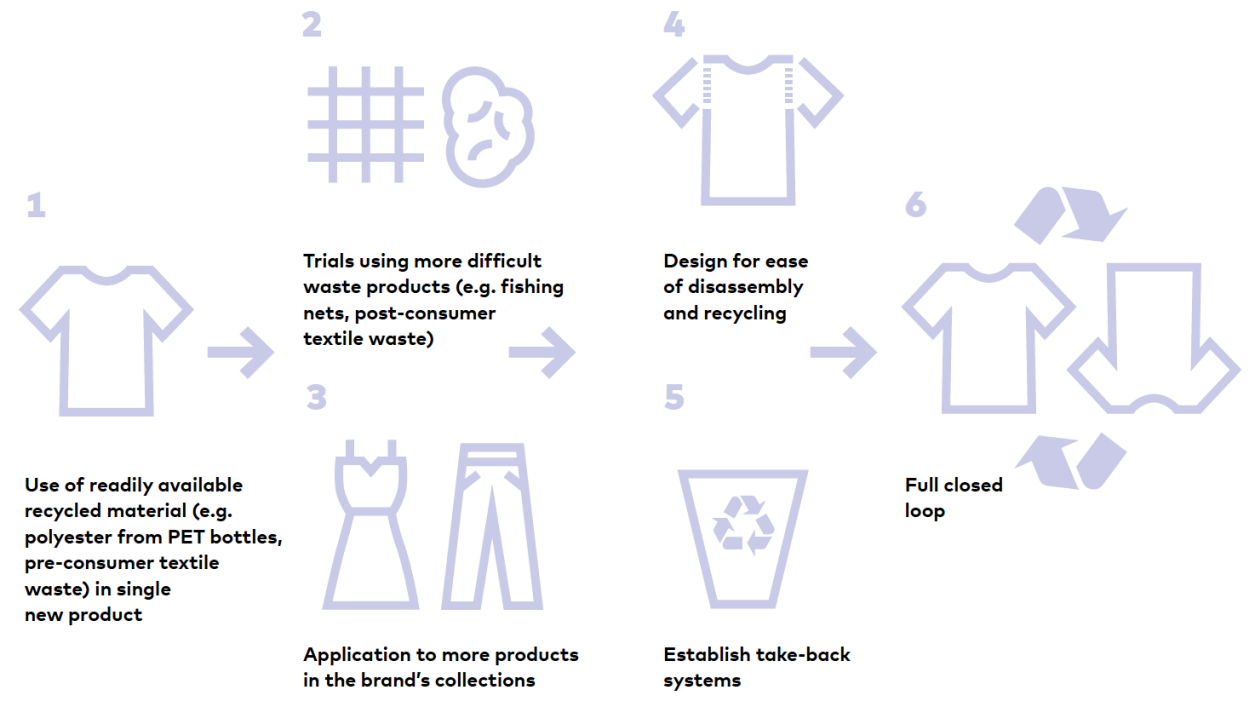

Source: Own making.

Designing for recycling lies further along the process, in part because its usefulness is dependent on effective systems being in place to collect and process post-consumer textile waste.

Moreover, for the brand itself to gain economically from design for recycling it needs to have its own take-back system in place. Design for recycling may eventually lead to take-back systems and closed loops. As we saw with Houdini, once a closed system is in place, it can be a key catalyst for spreading design for recycling and closedloop thinking to other products in a brands range.

However, brands are not necessarily following the same pathways. Some like Elsk are designing for recycling, but not planning to establish take-back systems themselves to make use of this design. H\&M on the other hand has a collection system for used textiles but is not yet implementing design for recycling. These different approaches reflect both the size of companies, but also the different visions that the companies have of the future.

This is considered further in Chapter 4. First, however, we'll consider the challenges that brands and their upstream and downstream partners are facing on the journey.

\subsection{Challenges and Solutions}

Representatives from brands and their upstream and downstream partners, pinpointed a range of key challenges in the use of recycled textile fibres and in design for recycling. Several have succeeded in overcoming, or working their way around, at least some of these. Other challenges remain yet to be solved. 
"Everything that is done outside the regular supply chain is challenging. It requires extra work and new routines for the whole organisation."

In all cases solving challenges requires time and resources but many brands feel that the long-term benefits make this difficult transition worthwhile.

\subsubsection{Challenges in use of recycled materials}

Retaining durability and quality of products

Retaining the quality and strength of products is an important issue to many of the interviewed brands. Filippa $\mathrm{K}$ has a 10-year warranty on selected Front Runner garments. Houdini's customers expect its products to last under challenging outdoor conditions. Nortex' healthcare pillows and duvets need to be resilient to up to 100 washes at high temperatures in hospital laundries. Touchpoint's work wear must withstand and be comfortable under tough and highly variable working conditions.

These and several other brands stressed that using recycled fibres and fabrics must not compromise durability or quality. Partly because this would compromise their brand and customer expectations, but also because as a few also stressed, a longer lifetime gives far higher environmental savings than the use of recycled fibres.

The most often mentioned challenge by brands in this context is difficulties with finding recycled-content yarns and fabrics of sufficient quality despite recent improvements in availability.

According to interviewed brands, ten years ago recycled materials underperformed in terms of the feel of the material, tear strength, pilling and performance. Today there are more and more yarns and fabrics of good quality on offer as the markets for at least some types of recycled materials mature. However, individual suppliers' ranges of textiles with recycled content still remain limited compared to the range of virgin fibre based fabrics.

"In 2005, suppliers felt that the quality didn't need to be as good as fabrics from virgin - they should 'look' recycled. Now there are more and more recycled yarns and fabrics on offer of good quality."

Current lack of mature chemical recycling technologies leaves mechanical recycling as the only option for many textile fibre types. Mechanical recycling shortens and weakens fibres that have already been shortened by wearing and laundering in first generation garments (Östlund et al. (2015).

"We cannot lower our quality requirements. This means that it is not always possible to replace virgin fabrics with recycled ones." 
Brands and designers struggle to find the right balance between use of recycled materials and durability of garments. The use of recycled fibres can challenge durability due to pilling and other reasons.

Smaller brands face the additional challenge that many suppliers of recycled fibres have minimum orders. This results in difficulties to find suppliers of smaller batches, particularly when a brand has special requests such as using $100 \%$ recycled fabrics. For a fabric to be $100 \%$ recycled both the warp and the weft must be made from recycled fibres. Whereas the weft runs across the breadth of the fabric and can relatively easily be inserted as recycled yarns in a required batch length, the warp goes along the whole production length. To produce $100 \%$ recycled fabrics the entire production length would need to be from recycled yarns. Typically a single production batch is between 10,000 and 30,000 yards and small brands can often not make use of such large quantities. Moreover, single small orders might not provide sufficient incentive for textile recyclers to develop new materials.

"Large producers are willing to do small tests but then they will expect this to be followed up by large orders."

Another limitation is low availability of recycled materials of certain fibre types such as wool, of which insufficient volumes are collected and sorted for recycling. This is in part due to the fact that many used textile collection operations, for both economic and legal reasons, do not accept or encourage households to deliver non-reusable clothing which would otherwise be available for recycling markets.

Using recycled fibres - and staying competitive

The brands face the challenge of maintaining economic competitiveness when using recycled fibres in new garments as engaging in the use of recycled content can be expensive.

Firstly, more than half of the interviewed brands consider the current price levels for recycled textile fibres a challenge for increased use of recycled textile fibres. Recycled fibres and fabrics generally remain more expensive than virgin materials in part due to economies of scale, limited supplies of material for recycling and lack of maturity of the recycling industry and technologies for post-consumer textiles. A few brands expect this to change within the next ten years.

Some sources of recycled textile fibres are already economically competitive with new materials. Waste recycler and textile company, Pure Waste, found that many textile factories in India are already making use of pre-consumer factory waste (i.e. offcuts and spinning waste) in the production of new fabrics. Paradoxically, the factories see this as a means for reducing costs but often hide this from their clients for fear of being accused of cutting corners and compromising quality. They see the use of recycled fibres as a money saving opportunity but certainly not as a selling point to consumers. This illustrates a need for better communication between brands and their suppliers (see later). 
Secondly, there are many investment and R\&D costs associated with using recycled fibres. Brands with experience in using recycled textile fibres testify that at least during initial development periods, venturing outside the regular supply chain is challenging, time consuming and expensive as it requires new routines and handling from the whole organisation. These additional costs should reduce as the market matures and use of recycled fibres is mainstreamed.

"High prices on recycled materials are not where the problem lies. The real problem is that the standard demand is for virgin materials and that it is more time consuming to look for recycled materials."

Knowing where fibres come from

Both brands and suppliers see a current lack of transparency and traceability in the supply chain regarding input material, the origin of textile waste and types of recycling processes. Transparency and traceability become particularly challenging as companies move from pre-consumer to post-consumer waste since post-consumer waste can come from a wide range of brands and producers making use of many different production processes.

"We need more knowledge regarding risks in closed loop systems, especially related to contaminated work clothing and material with functional finishes such as fire retardants."

Transparency in the source of recycled fibres is necessary, in part, because of a perceived risk that traces of hazardous, persistent chemicals in textile and non-textile waste will find their way into new garments and textile products (see also Schmidt et al., 2016, Swedish Chemical Agency, 2014).

Transparency in the supply chain is also necessary so that brands know that the recycled-content yarns and fabrics they are buying, really do have the recycled content that is claimed. Suppliers themselves also need assurances on the waste material they are buying.

"Chemicals used in the recycling processes themselves may be problematic and result in that the recycled material cannot meet certification criteria."

Some brands and suppliers of recycled-content yarns reported that they have experienced or have heard of cases where the recycled-content is not genuine. This can be a direct result of the increasing demand and the higher price being paid in some cases for recycled content. As an example, two brands named fibres recycled from PET 
bottles that have never been used, and were only produced to become a source of recycled fibres.

Other challenges

Both brands and suppliers point to a communication gap between the actors in the value chain as a further challenge. There is a lack of common language and common understanding on what brands wish for, on the one hand, and what can be realized by suppliers on the other. It can also be a challenge for brands to find a supplier of materials with the particular characteristics they need for their products.

A further obstacle named by a number of brands, is also part of the background to this report; many used garments are not easily recyclable under current recycling technologies. A large share of garments and home textile products are produced using mixes of fibre types to give certain functionality such as stretch or increased strength or simply to reduce product prices. Under current technologies only pure recycled fibres can act as feed for new textile products. Products may also include additional materials in labels, seams, threads, plastic prints and functional treatments etc. that requires disassembly prior to recycling. This reduces the availability of used clothing and textiles that are fit for fibre-to-fibre recycling and thus reduces the availability of recycledcontent yarns.

In connection with this, a lack of automated sorting technologies for separating postconsumer textile waste by colour and fibre types is also holding back large-scale fibre recycling. Such technologies would reduce the cost and increase the availability of recycled fibres and materials.

\subsubsection{Strategies to overcome challenges}

As described under Section 3.4, despite the challenges named above, a number of brands have taken strategic decisions to use recycled fibres in their garments. For some, the use of recycled fibres constitutes their core business. Others are traditional brands gradually shifting their business model from virgin to recycled textile fibres.

The challenges faced by both these business types are largely the same, even if the approaches for overcoming them might differ. The solutions are divided in this section into strategies that are currently being applied by the interviewed companies (see Figure 4), and strategies/solutions for increased use of recycled fibres that are not yet available, or not being practised (see Figure 5).

Some strategies address more than one of the challenges identified in the previous section. Figures 4 and 5 illustrate which challenges are addressed by each strategy.

Strategies that are already being practised

Strategy 1: good supply chain communication is an important strategy in developing desired fibres and to get access to textiles containing recycled fibres. It is critical to find good cooperation networks as recycled-content fabrics are often a result of constant dialogue between a brand and its suppliers. 
Brands such as Lindex and Peak Performance decided what they wanted to achieve in terms of use of recycled textile fibres and then specifically searched for partners and suppliers who were interested in working together towards the same goals. Others such as Nortex and Houdini worked with their existing suppliers in moving towards these goals.

"It is important for us that our suppliers share our vision, so we were in it together and can inspire each other. This also means that we seldom change or find new fabric suppliers - long relationships are important."

Strategy 2: creating own supply chains One brand, Pure Waste, produces cotton garments from yarns made of $100 \%$ recycled factory waste. In order to achieve this, Pure Waste chose to create its own supply chain and develop recycling processes.

The decision to produce the yarns and fabrics themselves emerged from difficulties to find suppliers of sufficient and regular quantities of yarns and fabrics made using preconsumer waste - the first main challenge named earlier. Creating own supply chains enabled small-scale production, own process and quality control and building and adjustment of equipment. It contributed both to increasing the quality of the recycled fibres, improving the availability of recycled fibres. 
Figure 4: Currently applied strategies for overcoming challenges to use of recycled materials

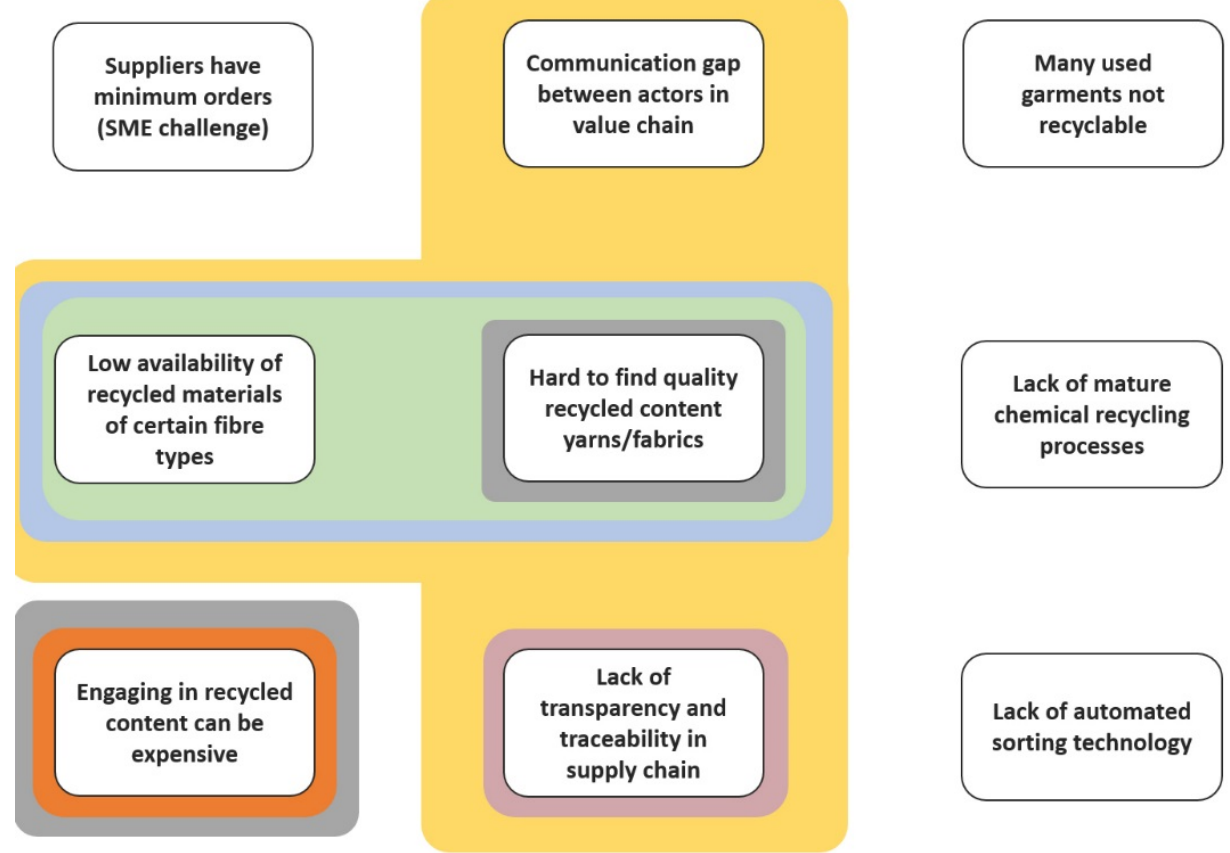

\section{Strategies:}

1. Good supply chain

communication

2. Creating own supply chains

5. Use/start with available materials
3. Using

transparency/traceabil ity standards

6. Commitment at leadership level

Strategy 3: Using transparency/traceability standards Many brands currently work with standards in order to improve transparency and traceability of textiles. This is both to ensure that the material the brand is buying from suppliers really does contain recycled content and to prevent cross contamination by persistent chemicals.

"We require all recycled materials we use to be certified, and we request this documentation prior to placing orders."

The Recycled Claim Standard (RCS) $)^{9}$ and Global Recycled Standard (GRS) ${ }^{10}$ are certification system that can assure actors in the value chain of the genuine nature of recycled content. H\&M, Peak Performance and Elsk are examples of brands that are making use of these standards. Touchpoint meanwhile, audits its suppliers itself to

\footnotetext{
9 http://textileexchange.org/
}

$10 \mathrm{lbid}$. 
ensure that recycled PET actually comes from used bottles and not from bottles produced for the sake of recycling.

Houdini uses Bluesign ${ }^{\circledR 11}$ to ensure that its products do not contain hazardous chemicals. All actors along the supply chain are audited to ensure that they are not using these chemicals in the production process and this also extends to suppliers of recycled materials. Global Organic Textile Standard, GOTS, ${ }^{12}$ and OEKO-TEX ${ }^{\circledR 13}$ have similar systems for assuring lack of hazardous chemical content.

Strategy 4: Strong consumer communication During these relative early days of using recycled content, a number of brands overcome issues of higher costs and technical challenges in quality via actively communicating these challenges to their consumers.

"Our knitted shirt made from recycled jeans is valued for its quality. Unlike for example a shirt made from merino wool, the quality is communicated by its sustainability story and not its softness."

Filippa K, for example, experienced problems with burling for a specific product containing recycled fibres. Although the product did not fulfil the brand's normal quality standards the brand decided to go ahead with sales and give special treatment instructions to its customers. The company hoped that consumers would be sympathetic to its goal of striving towards more sustainable materials.

Elsk has a similar strategy, believing that sustainability can be communicated as another form of quality, with just as much value as the softness of virgin kashmir.

Strategy 5: Use/start with available materials Available fibre-to-fibre recycling of natural fibres such as cotton and wool is based on mechanical recycling processes (Östlund et al., 2015). New chemical recycling processes are under development and brands are eager to test them. The expectation is that such recycling processes are less wearing on the textile fibres and will allow higher shares of recycled fibres in durable products.

Until such technologies are available brands that want to use recycled content are using fibres from mechanical recycling. This is a good starting point for brands to begin engaging and means that they will have commitment, procedures and strategies in place to react quickly when other types of recovered materials and recycling processes become available.

Several brands stress, though, the need to blend mechanically recycled fibres with virgin fibres in garments. H\&M finds the limit for using mechanically recycled cotton in new products to be about $20 \%$ for post-consumer textile waste. Filippa $\mathrm{K}$, uses up to $80 \%$ recycled wool fibres depending on the quality needed.

\footnotetext{
${ }^{11}$ https://www.bluesign.com/

12 http://www.global-standard.org/

${ }_{13} \mathrm{https}$ ///www.oeko-tex.com
} 
Strategy 6: Commitment at leadership level Using recycled textile fibres is still rather new for most brands and therefore challenging, time consuming and expensive. Engaging in increased use of recycled fibres means that the whole organisation must adapt to new routines and devote extra work hours.

Several brands stress the critical importance of including goals on use of recycled fibres in garments as elements of a strategy with backing from the top management. With buy-in at top management, the door is even open to sustainability thinking becoming part of everyone's responsibilities and approach rather than just the top management or the company's sustainability manager. In that way each product is designed with sustainability in mind from the outset.

\section{Future solutions}

Even if brands and their suppliers are already finding ways to (partly) overcome challenges, the interviewed companies stressed some areas where they see a need for other strategies and approaches in the future (see Figure 5). All of these require or would be strongly assisted by more cooperation across the industry.

Strategy 7: Targeted innovation and research Research into chemical recycling processes, automated sorting machines of used textiles into different fibre types is already underway. For example, Swedish chemical recycling company, Renewcell, has found funding from various sources, the EU program Trash-to-Cash ${ }^{14}$ is funding VTT and Swerea within a number of innovation areas including chemical recycling, the privately funded Mistra Future Fashion programme includes research into chemical recycling. Other programmes such as Vinnova in Sweden are funding projects such as the SIPTex project ${ }^{15}$ developing automated sorting of used textiles for recycling. The EU's Ecoinnovation initiative earlier funded a similar R\&D project in the Netherlands (Textile4Textile). ${ }^{16}$

There are many other such examples of R\&D in these areas. However, there is perhaps a need for a stronger level of coordination between these projects, or a hub where brands and other industry stakeholders can follow progress in all these areas and where goals can be identified.

\footnotetext{
${ }^{14}$ http://trash2cashproject.eu/

15 http://www2.vinnova.se/sv/Resultat/Projekt/Effekta/2011-01544/SIPTex--Svensk-Innovationsplattform-for-

Textilsortering/

${ }^{16}$ https://ec.europa.eu/environment/eco-innovation/projects/en/projects/t4t
} 
Figure 5: Future strategies to overcome challenges in the use of recycled materials

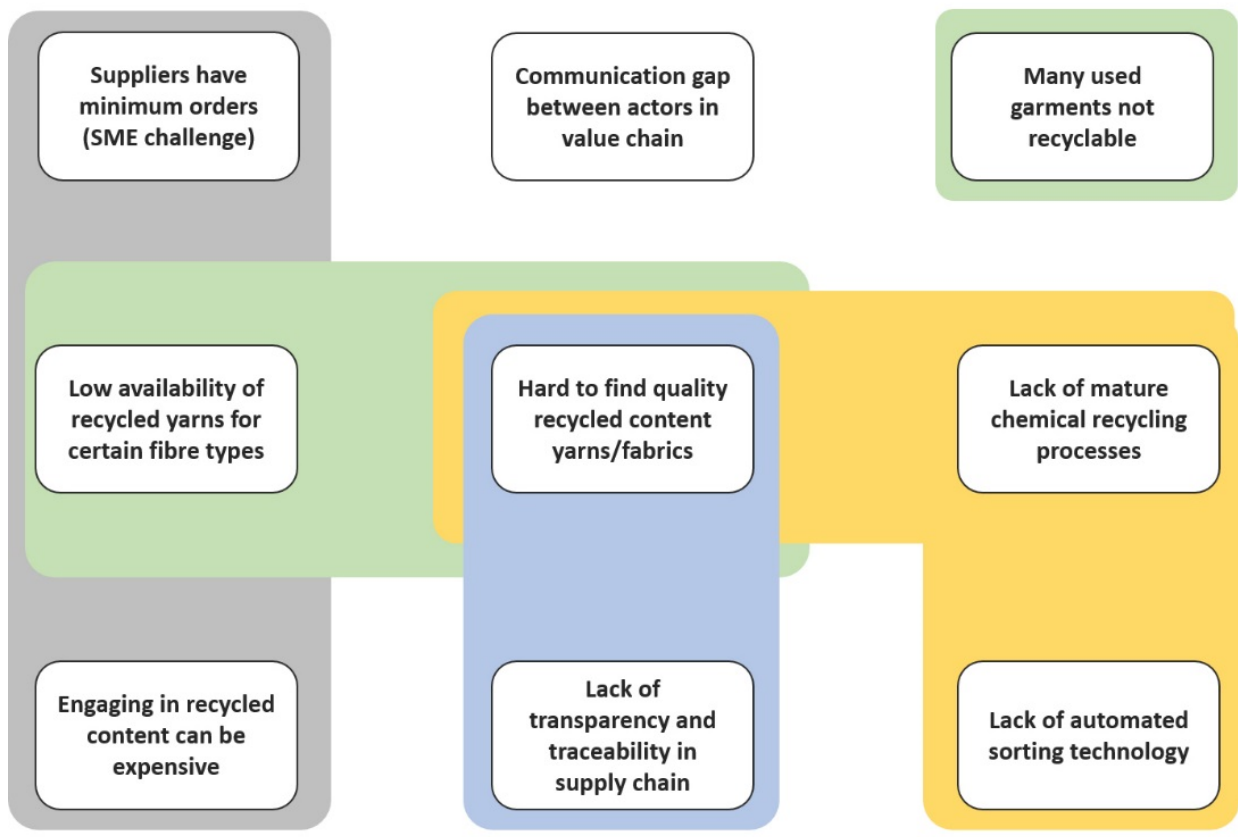

Strategies:

7. Targeted innovation and research

8. Risk assessment of closed loop systems

9. Cooperation between small brands

10. Design for recyclability/ longevity

Strategy 8: Risk assessment of closed loop systems. Another area in need of more research and sharing of knowledge across the industry, concerns the risks associated with cross-contamination of chemicals posed by closed loop systems. Broad assessments of the risk have been carried out by, amongst others Schmidt et al. (2016) but there is a need for more rigorous risk assessments for particular processes and products. This would provide brands with a better knowledge of the risks associated with closed loop and how these can be avoided.

Strategy 9: Cooperation between small brands would enable them as a group to approach suppliers of recycled-content yarns and fabrics. This would give suppliers greater confidence in developing new products. The cooperating brands would also have more possibility for fulfilling minimum batch orders. Such close cooperation must overcome natural tendencies to see each other as competitors. A further requirement for cooperation would be that the brands had similar material needs.

Strategy 10: Initiatives on design for recyclability. Recyclers and suppliers of recycled content see a need for better knowledge, standards and better education in how to design garments such that they can provide a source of recovered materials at the end of their lives. Design for ease of recycling is covered below. 


\subsubsection{Challenges and solutions to design for recycling}

The interviewed brands and recyclers pinpointed three main challenges for improving the design for recycling of garments (see Figure 6).

"Designers might not be equipped for designing for recycling. It requires thinking a step further from what they are normally concerned with. For many companies these considerations are not part of the standard design process."

They see a lack of knowledge/awareness amongst designers and suppliers on both how to design for ease of recycling and why. It takes time to gain knowledge and to choose materials that are easy to recycle. Designers also need more information on how prints and functional treatments affect recyclability. Suppliers might lack understanding of the wish to design for recyclability, and e.g. not understand why brands would want to use mono-materials.

"Even if the designers had sufficient knowledge other sections of the company would challenge them."

A further challenge, is that recyclability is just one of several functional considerations in the design process. Other considerations often have higher priority. It can e.g. be a question of mixing fibre types in order to give the product a specific expression or to give stretch, a matter of durability that overrules the ambition to design for recyclability, or a need for a combination of lightness and warmth, which might suggest a fibre mix.

These wished for characteristics are often in conflict with design for recycling. For some products it is still not possible to find recyclable fabrics and products that meet these other prioritised functional needs. Products made from single fibre types, for example, may often be less durable than products made from fibre mixes and several brands (e.g. Houdini, Filippa K, Nortex, Peak Performance) stress that durability is more important than recyclability in its design process. In this case the conflict is not bad from an environmental point of view since extending lifetimes brings greater benefits than recycling end of life (Schmidt et al., 2016). However, ideally materials should be found which are both durable and fit the other desired functionality and are recyclable.

One brand, Filippa K, also mentioned the lack of inspiring examples for designers on how circularity can be implemented at the design stage. 
Figure 6: Strategies for overcoming challenges to design for recycling

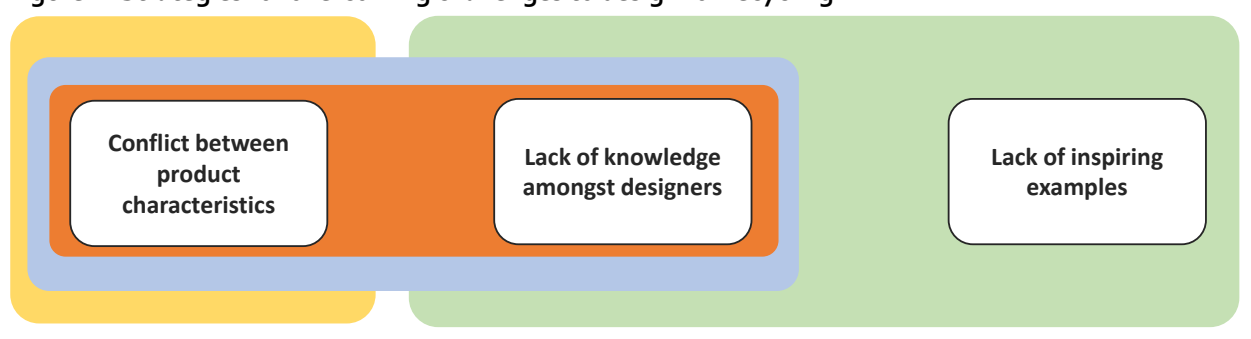

Strategies:

$$
\begin{aligned}
& \text { 1. Education } \\
& \text { for designers } \\
& \text { 3. Establishing } \\
& \text { material libraries }
\end{aligned}
$$

2. Top-level strategic decisions

4. Participating in networks

The strategies that have been used by, or can be envisaged by, brands and other partners for overcoming the challenges above include:

Strategy 1: Education for designers. This already exists to a certain extent in some design schools or via training programmes. Some brands (e.g. H\&M, Peak Performance and Filippa $\mathrm{K}$ ) have arranged for their designers to participate in courses on design for recycling. However, it is not the norm in design schools. There is a wish from brands, such as H\&M, that design for recyclability is included in the curricular of design schools so that it is embedded from the start.

Strategy 2: Top-level strategic decisions. Brands like Houdini and Peak Performance testify the importance of strategic internal decisions for a company that wants to improve the design for recyclability of its products. Sustainability principles, such as design for recyclability, need to be integrated into the entire company's ethos. However, these and other brands also recognise that from an environmental perspective, durability should not be compromised by recyclability. It is important that strategic approaches take on a broad sustainability goal and don't just focus on a single issue.

Strategy 3: Establishing material libraries. Brands can provide internal tools that assist its designers. Peak Performance, for example, has a fabric library from which its designers can choose fabrics that meet different functionality needs. The company is working through this library to include alternatives that meet the same function but are based on recycled/recyclable or other sustainable fibres. This provides the designer directly with sustainable materials without them needing to go out and find themselves. This is also part of a more general effort to remove the conflicts between recyclability and other wished for/necessary characteristics of a brand's products like durability, stretch, low-weight etc. through focused material research.

Strategy 4: Participating in networks. Participating and working in research, supplier and industry networks enables companies and designers to gain more knowledge regarding design for recycling as well as inspiring examples of brands and designers that have integrated aspects of recyclability in their products. 


\subsubsection{Challenges to implementing close loop recycling}

Many of the challenges associated with closed loop recycling are the same as identified for use of recycled content and designing for ease of recycling, since full closed loops include both these elements.

That which a closed loop includes but does not overlap with the other areas is the need for take-back systems for used textile products such that a brand can gain ownership of their post-consumer products ready for recovering materials from them for use in new products.

The interviewed brands mentioned two main challenges with establishing such systems. Firstly, it is hard to establish and implement global take-back schemes. The textile industry is a global industry. Most brands export to a range of different markets, with differing infrastructures, logistics and regulations. A take-back scheme that works in one country can be doomed to fail in another country.

Secondly, and connected with this, it can be expensive and inefficient to create a closed loop collection system for a single brand. Consumers are usually not sorting textile products according to different brands and producers. Collected post-consumer material will therefore usually contain a mix of garments and other textile products from different producers. This results in uncertainties in the fibre types and chemical content of the collected textile waste posing challenges for a close loop recycling.

One potential way of solving these challenges is via participating in collective closed loop system. Two examples of collective systems are the ECO CIRCLE system and the Re.Verso material exchange platform, both of which are described in Box 1 earlier in this report. However, in both cases, participating brands are still expected to gather their own post-consumer textiles which they then deliver to, or exchange via, the collective systems.

A further development of collective systems could be envisaged where a central organisation or where all participating brands are obliged to take-back post-consumer clothing from other participating brands. For this to work, some solutions would need to enable 1) automatically sort between different brand clothing in the system and 2) redistribute costs of collection so that larger participating brands compensate smaller brands. No examples were found of systems that are moving forward in these areas, although the French extended producer responsibility systems for textiles and footwear includes some elements of this 


\section{Future prospects for the industry}

Actors from all parts of the textile value chain are showing an ambition to make the textile value chain more circular and resource efficient. Starting with a limited number of frontrunners using recycled textile fibres, the issue of textile-to-textile recycling is beginning to pervade an increasing number of brands' strategic discussions and decisions.

In spite of, or maybe because of, the fact that fibre-to-fibre recycling of textiles is relatively new for most brands, the willingness to engage with suppliers as well as competitors to improve circularity of textiles is larger than in many other areas.

This is crucial as even with an increasing number of brands engaging in textile-totextile recycling, there is a range of areas to address in order to stimulate the demand for recycled textiles. The interviewed brands, suppliers and other partners provided their perspectives on the need

- to increase the use of recycled fibres from niche to mainstream

- to intensify value chain dialogue

- for common quality requirements

- for a strategic coalition increasing the demand for recycled textile fibres.

Brands comments on these perspectives are summarised below.

\subsection{Shifting the use of recycled fibres from niche to mainstream}

Increasing awareness among consumers is crucial for shifting the consumption of recycled fibres from niche to mainstream. However, consumer demand for textiles made from recycled fibres will only come once there is a supply.

"Consumers are smart and willing to adapt when knowledge and awareness increases."

According to many brands, the industry must be proactive and lead the way by providing the market with recycled products and communicate on the availability and the reasoning behind to consumers. The industry needs to be clearer in informing the consumer on good and less good choices. Increased use of certification and labels with criteria for use of recycled textile fibres can contribute to this. 
"It is easier to spread the message in media when it comes from various sources."

Some brands also feel that increasing the demand for recycled products is a joint responsibility. As the textile sector has to look for new options and make recycled textiles more visible, governments can speed up the demand by creating incentives.

Several of the interviewees also stress the need for media to get involved in order to increase awareness. This requires, in turn, a common effort from different actors in the textile value chain including research institutions and consumer associations.

In addition to increased consumer awareness, there is a need for increased awareness within businesses. Sometimes the hurdle is not so much a lack of knowledge of recycling opportunities, but rather a lack of awareness of the potential eventual economic benefits of engaging in recycling. It is therefore crucial that brands (frontrunners) demonstrate that it can be profitable for businesses to engage in recycling.

\subsection{Value chain dialogue for increased use of recycled fibres and design for recycling}

A majority of the interviewed brands and recyclers stressed the importance of a close value chain dialogue to increase the use of recycled fibres and improve the design for recycling.

"Cooperation is key. Supply chain efforts is a must to be successful."

Part of this dialogue is coming to an understanding via a common language of what brands desire and what is possible for suppliers to provide in the design and development of new products. Brands must increase their knowledge in availability and properties of recycled fibres and of recyclable materials. This also helps setting goals for minimum recycled content and recyclability of their products.

Suppliers must gain a better understanding of the reasoning behind the brands' material specifications, e.g. regarding mono-materials and durability. Several of the interviewed brands confirm that they have long-term partnerships with their suppliers enabling them to jointly develop new fabrics.

"If we work together we will develop sharper solutions and better knowledge." 
Smaller brands might profit from a closer cooperation in order to get more leverage towards suppliers and better economy of scale. When brands work together, company secrets and exclusivity can be an obstacle. However, one brand, Houdini, has chosen to communicate its recycling efforts and experiences openly, arguing that they can have this type of dialogue without missing competitiveness.

\subsection{Common quality requirements on recycled textile fibres}

Certifications often lead to an administrative burden, but can also help push the market in the right direction. Some of the interviewed brands think that common eco-design criteria and quality requirements for textile products would be beneficial to increase sales and give credibility to brands engaging in recycling. However, they and some suppliers argue that common quality requirements should be applicable for textiles regardless of whether they are produced from virgin or recycled materials.

"It is sad to have to force the industry to use recycled and think recycability. Better to be able to show that businesses that are engaging are still profitable. Successful frontrunners are of key importance."

Several brands stress the importance of global, or at least EU wide, standards as the textile industry is a global industry, working with global supply chains, where brands are active on many different markets.

These may not necessarily mean new standards. H\&M and Nortex, for example, refer to existing standards, and argue that there is no or very limited need for additional quality standards or for standards regarding recycled content in garments and other textile products.

\subsection{Strategic coalition for increased marked demand for recycled fibres}

There were some mixed views on the need for a strategic coalition to increase demand. One larger brand felt that they were already engaged in initiatives at various international levels that could partially contribute to increasing demand for recycled materials and one more network might stretch their resources too thin.

"It would be best to work together to avoid each company reinventing the wheel for themselves."

Smaller brands, however, saw a need for greater cooperation and exchanges, to learn from each other's experiences and move forward together, and would be very willing to engage in such a coalition. According to one company, this should include market 
leaders from both the fashion industry and home textiles producers as well as branch organisations. The company stressed the need for more sparring between companies on available technologies, suppliers of recycled yarns and emerging recycled materials. 


\section{References}

EEA, (2013). Environmental pressures from European consumption and production. EEA Technical Report No 2/2013. http://www.eea.europa.eu/publications/environmental-pressures-fromeuropean-consumption

Elander, M. \& Ljungkvist, H. (2016). Critical aspects in design for fiber-to-fiber recycling of textiles. Mistra Future Fashion report 2016:1 Stockholm: Mistra Future Fashion.

JRC (2014) Environmental Improvement Potential of textiles (IMPRO Textiles). Joint Research Centre Scientific and Policy Reports. European Commission.

Lexén, J., Loh Lindholm, C., Youhanan, L. \& Stenmarck, Å. (2016). Recommendations for sorting out textiles containing hazardous substances from the material loop. SMED report No 175 .

Palm, D., M. Elander, D. Watson, N. Kiørboe, H. Salmenperä, H. Dahlbo, K. Moliis, K.A. Lyng C. Valente, S. Gíslason, H. Tekie, S. Harris, T. Rydberg (2014): Towards a Nordic textile strategy: collection, sorting, reuse and recycling of textiles. Temanord Report for the Nordic Council of Ministers. https://doi.org/10.6027/TN2014-538

Rijkswaterstaat, (2017) European Textiles \& Workwear Market: the role of Public Procurement in making textiles circular. Report under the European Clothing Action Plan programme.

Schmidt, A., Watson, D., Roos, S., Askham, C. \& Brunn Poulsen, P. (2016). Gaining benefits from discarded textiles: LCA of different treatment pathways. TemaNord report from Nordic Council of Ministers. https://doi.org/10.6027/TN2016-537

Swedish Chemical Agency (2014). Chemicals in Textiles-risks to human health and the environment. Report from a government assignment. Report 6/14.

Tojo, N., Kogg, B., Kiørboe, N., Kjær, B. and Aalto, K. (2012). Prevention of textile wastematerial flows of textiles in three Nordic countries and suggestions on policy instruments TemaNord 2012:545, Nordic Council of Ministers. https://doi.org/10.6027/TN2012-545

Thompson, P., Willis, P., Morley, N. (2012). A review of commercial textile fibre recycling technologies. Report by Oakdene Hollins for WRAP, UK.

Tukker, A., Huppes, G., Guinée, J., Heijungs, R., de Koning, A., van Oers, L., Suh, S., Geerken, T.,van Holderbeke, M., Jansen, B. \& Nielsen, P. (2006). Environmental impacts of products (EIPRO) Analysis of the life cycle environmental impacts related to the total final consumption of the EU-25, Sevilla: Institute for Prospective Technological Studies, EUR 22284 EN

Watson, D., Palm, D., Syversen, F., Brix, L., Amstrup, M. and Nielsen, R. (2016). The Fate and Impact of Used Textiles Exported from Nordic Countries. TemaNord 2016:558, Nordic Council of Ministers. https://doi.org/10.6027/NA2016-905

Watson, D. and Fischer-Bogason (2017). Greener textiles in hospitals: Guide to green procurement in the healthcare sector. Nordic Council of Ministers ANP2017:717.

https://doi.org/10.6027/ANP2017-717

Östlund, Å. et al. (2015). Textilåtervinning - Tekniska möjligheter och utmaningar. Rapport 6685 . Stockholm: Naturvårdsverket. 



\section{Sammenfatning}

\section{Baggrund}

Forlængelse af tekstilprodukters aktive levetid via fx genbrug er en vigtig måde at reducere tekstilprodukters miljøpåvirkning på og bør derfor prioriteres. Alle tekstiler bliver dog i sidste ende slidt op, hvorefter de skal håndteres som affald. Genanvendelse af tekstilaffald til nye tekstilvarer er miljømæssigt fordelagtigt i forhold til forbrænding eller deponering, men udnyttes i øjeblikket kun i begrænset omfang.

I 2015 lancerede Nordisk Ministerråd en handlingsplan for bæredygtig mode og tekstiler; Norden - velklædt i et rent miljø. Et af målene her er at "understøtte forretningsmodeller, der fremmer genanvendelse af fibre til nye tekstilvarer."

Dette projekt har understøttet dette formål gennem tre leverancer:

- En case wallet ${ }^{17}$ som præsenterer 10 brands, der beskæftiger sig med cirkulær tænkning. Intentionen med case wallet er at inspirere andre brands til at engagere sig.

- Denne rapport, der indeholder en tværgående analyse af udfordringer, som brands har oplevet og strategier, de har valgt for at overvinde disse.

- En workshop afholdt i Stockholm den 27. september 2017, der samlede brands, leverandører af genanvendte materialer, indsamlingsorganisationer og forskere, for at diskutere samarbejdsmuligheder.

\section{Nordiske brands på vej mod genanvendelse}

Fremme af tekstil-til-tekstil genanvendelse kræver en indsats flere steder i tekstilværdikæden. En stabil forsyning af genanvendelige brugte tekstiler skal sikres, og efterspørgslen efter genanvendte fibre skal øges.

En række nordiske brands er engageret $\mathrm{i}$ at finde løsninger, både ved at designe med henblik på at gøre det lette at genanvende tekstilerne efter endt brug og dermed øge den potentielle forsyning af genanvendte fibre, og ved at anvende genanvendte materialer i nye produkter. Elleve brands samt nogle af deres nøglepartnere er blevet interviewet for at identificere deres motivation, de udfordringer de har oplevet undervejs, og hvordan de har overvundet disse samt hvordan genanvendelse kan fremmes i branchen som helhed.

${ }_{17}$ Offentliggjort af Nordisk Ministerråd i en parallel dokument: Textile-To-Textile Recycling: Ten Nordic brands that are leading the way. 


\section{Reaktion på ressourceknaphed}

De deltagende brands handler på en stigende erkendelse af, at industrien skal tage ansvar for at reducere sit pres på jordens ressourcer i lyset af den voksende globale befolkning. Et skifte til en cirkulær økonomi har desuden en langsigtet strategisk betydning for branchen ved at sikre en fremtidig forsyning af materialer.

\section{Mest fokus på genanvendt materiale}

Alle interviewede brands bruger garn/stoffer med genanvendt materiale i udvalgte nye produkter. Blandt de genanvendte materialer er: polyester genanvendt fra PET-flasker, nylon fra fiskenet og mekanisk genanvendt bomuld og uld. To brands fremstiller nye produkter baseret på brugte tekstiler fra forbrugerleddet. Nogle brands designer også produkter med henblik på at gøre det lettere at genanvende ved at undgå fiber- og materialeblandinger, og nogle laver designs for at lette adskillelsen af de forskellige materialer.

Færre brands udvikler eller er en del af lukkede kredsløbssystemer. Disse systemer kræver ikke kun design af produkter, hvorfra materialer kan anvendes igen til næste generation, men også systemer til indsamling af brugte tekstilprodukter.

\section{Et konstant skiftende billede}

Denne rapport tegner et øjebliksbillede af en branche i udvikling. Alle de brands, vi har talt med, har forpligtet sig til at bevæge sig mere ind i den cirkulære tankegang $\mathrm{i}$ fremtiden. For mange brands har udgangspunktet været at anvende genanvendte kvalitetsfibre med høj og let tilgængelighed, såsom genanvendt PET eller preconsumer bomuldsaffald fra fabrikker.

Design skabt med henblik på genanvendelse har hidtil ikke fyldt så meget, blandt andet fordi det er afhængig af effektive systemer til indsamling og behandling af det brugte tekstilaffald. Design til genanvendelse kan i sidste ende føre til tilbagetagningssystemer, der kan fungere som katalysator for at sprede en cirkulærtankegang til andre produkttyper, når først systemet er på plads.

Alle brands beskæftiger sig med genanvendelse som en del af en bredere dagsorden omkring bæredygtighed eller cirkulær økonomi. I denne sammenhæng understregede flere brands, at brugen af genanvendte fibre ikke må ske på bekostning af holdbarhed eller kvalitet. Blandt andet fordi det ville kompromittere deres brand, men også fordi en længere levetid giver højere miljøbesparelser. Ikke alle brands er dog lige opmærksomme på denne prioritet.

Alle brands har oplevet udfordringer i forbindelse med implementering af cirkulære ideer, men de har samtidigt også udviklet en række strategier for at løse disse udfordringer. Disse strategier kan potentielt anvendes af andre brands, der ønsker at involvere sig i cirkulær økonomi. 


\section{Involvering på ledelsesniveau}

Når et brand engagerer sig i brugen af genanvendte fibre, kan det muligvis påvirke indtjeningen i den indledende fase, blandt andet fordi genanvendte fibre på nuværende tidspunkt er dyrere end jomfruelige fibre, og også fordi det at bevæge sig udenfor de normale forsyningskæder kræver nye rutiner. Derfor er det vigtigt, at involveringen sker på højeste ledelsesniveau.

\section{Tæt samarbejde med leverandører}

Brug af genanvendte fibre i nyt tøj, og design med henblik på genanvendelse ved for eksempel brug af tekstil fremstillet af én enkelt fibertype, kan påvirke andre ønskede kvaliteter ved produkterne, såsom holdbarhed, komfort, lav vægt eller stretch. De involverede brands har løst denne udfordring gennem tæt samarbejde med deres leverandører, hvor de I fællesskab udvikler produkter, der både kan leve op til de funktionelle krav og samtidigt indeholde genanvendt materialer eller være genanvendelige. Et brand er gået et skridt videre ved helt at overtage produktionen af tekstil med genanvendte fibre.

Når først det genanvendte materiale eller de genanvendte fibre er blevet udviklet eller identificeret, kan disse gøres let tilgængelige for et brands designere til brug $\mathrm{i}$ fremtidige produkter. Et brand har udviklet et materialebibliotek, der identificerer bæredygtige materialevalg for alle de karakteristika, som en designer kan efterspørge.

\section{Kommunikation med kunder}

Tydelig kommunikation til kunderne om, hvorfor brandet beskæftiger sig med genanvendte fibre og design for genanvendelse, kan bane vej for at øge priserne på produkterne for at dække meromkostninger. Det kan også medvirke til at ændre kundernes forventninger til kvalitet, så bæredygtighed i højere grad formidles som en kvalitet over for kunderne.

\section{Brug af gennemsigtighed og sporbarhedsstandarder}

Det er vigtigt for brands at opnå sikkerhed for, at det, de køber som genanvendte materialer, reelt også indeholder genanvendte fibre, og at de genanvendte fibre ikke indeholder skadelige kemikalier. Nogle brands arbejder med standarder som Global Recycle Standard eller BlueSign for at opnå denne sikkerhed. 


\section{Fra niche til mainstream}

Selv om cirkulær tankegang er kommet på dagsordenen hos mange brands, er udbredelsen stadig relativt begrænset. En generel observation blandt de deltagende brands er, at industrien er nødt til at være proaktiv og ikke vente på at forbrugerne efterspørger det. Industrien skal udvikle sig aktivt og tilbyde sådanne produkter og udforske nye muligheder. Regeringer og medier har også en rolle at spille: Regeringerne ved at skabe incitamenter for industrien til at engagere sig og medierne ved at øge forbrugernes bevidsthed om den cirkulære økonomi i relation til tekstiler og dets miljømæssige og økonomiske fordele.

Samtidigt kan brands, der allerede har implementeret en cirkulær strategi, bidrage til at synliggøre, hvordan en cirkulær tilgang kan være profitabel og derigennem anspore andre brands til at vælge samme spor. Desuden er der behov for bedre viden, standarder og uddannelse af designere i, hvordan man designer beklædningsgenstande, så de efterfølgende kan genanvendes.

\section{Netværk og partnerskabers betydning}

Den cirkulære økonomi vil sandsynligvis medføre et behov for tættere partnerskaber i fremtiden. Deltagelse i netværk som Mistra Future Fashion, Ellen MacArthur Foundation mv. har givet brands kendskab til den nuværende udvikling inden for genanvendelsesteknologi og-innovation og gjort det muligt for designere og brands at inspirere hinanden.

Lukkede ressourcekredsløb kræver også større samarbejde. Ressourceudvekslingspartnerskaber som ECO CIRCLE og platformen Re. Verso har vist et potentiale for at øge samarbejdet mellem brands og leverandører via genanvendelsesvirksomheder samt hubs til materialeudveksling. Hvis branchen skal være cirkulær i en bredere skala, vil der være behov for flere typer af disse samarbejder.

\section{Koordineret forskning og udvikling}

Mange af de interviewede brands forudser en fremtidig udvikling, der vil ændre landskabet for tekstil-til-tekstil genanvendelse og løse de fleste af de nuværende udfordringer. Dette inkluderer blandt andet et gennembrud i kemiske genanvendelsesteknikker, der gør det muligt at genanvende blandede fiberprodukter, og desuden gør det muligt at omdanne materialer i tøj og andre tekstilvarer over mange produktgenerationer. Sådanne processer vil have brug for en fast og stor forsyning af kasserede tekstiler.

Et yderligere teknologisk fremskridt i denne sammenhæng er automatiserede sorteringsmaskiner, som hurtigt og omkostnings- effektivt kan sortere ikkegenanvendelige tekstiler efter farve og fibertype (herunder fiberblandinger). Begge 
typer teknologi er under udvikling i forskellige pilot- og forskningsprogrammer, men de involverede brands forudser et behov for en større koordinering af disse indsatser.

\section{Vent ikke med engagementet}

Selvom udviklingen af disse teknologier vil ændre branchen, er de interviewede brands enige om, at industrien skal involvere sig nu og ikke bare vente på lanceringen af disse nye teknologier. "Arbejd med hvad du har" har været et fælles mantra. Ved at engagere sig nu, viser brands vejen for en hurtigere tilpasning til de nye teknologier, i takt med at de opstår. 
Nordic Council of Ministers

Nordens Hus

Ved Stranden 18

DK-1061 Copenhagen K

www.norden.org

\section{STIMULATING TEXTILE-TO-TEXTILE RECYCLING}

Extending the active lifetimes of textile products should be prioritised in efforts to reduce the environmental impacts of textile production. However, once textiles are worn out, recycling them back into new textile products is environmentally advantageous compared to incineration or landfill.

A number of Nordic brands have been venturing out on pathways towards textile-to-textile recycling both through designing for ease of recycling and thus increase potential supply, and through using recycled materials in new products. This report compares the experiences of eleven of these and documents their motivation, challenges they've experienced and the strategies they've used to overcome these. The report is published in parallel with a case wallet and aims to inspire other brands to engage in closed loop thinking.

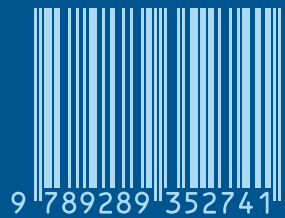

